\title{
The Bacterial Vaginosis among Pregnant Women in Jatinangor
}

\author{
Aw Wan Yi, ${ }^{1}$ Sunarjati Sudigdoadi, ${ }^{2}$ Hadi Susiarno ${ }^{2}$ \\ ${ }^{1}$ Faculty of Medicine Universitas Padjadjaran, Indonesia, ${ }^{2}$ Departement of Biomedical Sciences \\ Faculty of Medicine Universitas Padjadjaran, Indonesia, ${ }^{3}$ Department of Obstetrics and \\ Gynaecology, Faculty of Medicine, Universitas Padjadjaran/Dr. Hasan Sadikin General Hospital \\ Bandung, Indonesia
}

\section{Abstract}

Background: Bacterial vaginosis (BV) is polymicrobial that causes superficial vaginitis due to a shift in vaginal flora. In pregnant women, BV can result in a significant risk of some serious consequences. The objective of this study was to identify the BV prevalence and to explore the characteristics and personal hygiene practices among pregnant women.

Methods: This study was conducted in Desa Cipacing, Jatinangor, using the cross-sectional descriptive method, including pregnant women. The BV was detected by Gram-stained vaginal smears using Nugent Score. Furthermore, other microorganisms such as trichomoniasis and candidiasis were detected by direct microscopic observation. The questionnaire was distributed, consisting of details of personal hygiene practices.

Results: In total, $17.9 \%$ of 52 pregnant women included were diagnosed with BV and $14.3 \%$ with mixed infection. Pregnant women with BV were predominantly aged younger than 25 years $(61.1 \%)$, nullipara (50\%) and in a second-trimester pregnancy (50\%).

Conclusions: Bacterial vaginosis (BV) is common among young pregnant women, predominantly in their first pregnancy. It is related to personal hygiene practices, indicating the need for targeted interventions of healthcare education among these young pregnant women to reduce the BV prevalence.

Keywords: Bacterial vaginosis, personal hygiene, pregnancy, vaginal discharge

\section{Introduction}

Vaginitis is often assumed as a part of ordinary reproductive life in women since most of the childbearing age women experience some kind of vaginitis at least once in their life. The three most common etiologies of vaginitis are bacteria (bacterial vaginosis) accounts for 40$45 \%$, followed by fungi (candida vaginitis) for $20-25 \%$, and parasites (trichomonal vaginitis) for $15-20 \% .{ }^{1}$ Hence, bacterial vaginosis (BV) is an extremely prevalent vaginal condition and the number one cause of vaginitis in women of childbearing age. ${ }^{2}$ Phenomenon in $\mathrm{BV}$ is best to be described as polymicrobial, superficial vaginitis which involving a reduced amount of hydrogen-peroxide producing Lactobacillus, a normal aerobic vaginal microflora that later changes to a mixed anaerobic, Gram-negative or Gram-variable bacterial flora such as Mycoplasma hominis, Bacterioides species, Mobiluncus species, and Gardnerella vaginalis. ${ }^{3,4}$ Most of the women are usually reluctant to seek medical treatment when they come across with an abnormal vaginal discharge as they often misinterpret and assume it as a normal discharge. This 'culture of silence' is the one that shrouds the gynecologic morbidity. ${ }^{1}$ Women infected with $\mathrm{BV}$ are mostly asymptomatic. ${ }^{2}$

Globally, BV is common among reproductiveage women. ${ }^{5}$ The prevalence of $\mathrm{BV}$ in Asian pregnant women is quite high, for example in Japanese $(13.6 \%)$, in Thais $(15.9 \%)$, and Indonesian (18\%) women. $^{6}$ Furthermore, BV prevalence is also higher than that of other a symptomatic infectious diseases during pregnancy. ${ }^{6}$ Pregnant women with positive BV are at significant risk of some serious implications such as premature rupture of membrane, preterm labor and 
delivery, low birth weight infant, intraamniotic infection, chorioamnionitis, and post-cesarean endometritis. ${ }^{7}$ Previous study in Jatinangor has reported that out of a total of 2000 pregnant women attended to Public Health Center (Pusat Kesehatan Masyarakat, Puskesmas) Jatinangor in the year 2013, about 25\% were categorized under the high-risk pregnancy group, ${ }^{8}$ which is an alarming sign. Therefore, more attention should be given to pregnant women who are infected with BV.

An increase of attention is drawn because so far no data is available about the study of risk factors for $\mathrm{BV}$ in Indonesia. ${ }^{9} \mathrm{~A}$ recent study has proved that the asymptomatic BV prevalence is highest during the secondtrimester pregnancy, ${ }^{10}$ and that a higher frequency of genital infections is associated with inappropriate genital hygiene habits. ${ }^{11}$ The primary objective of this study was to assess the BV prevalence among pregnant women in Jatinangor. Also, the study aimed to explore the characteristics and personal hygiene practices as potentially modifiable risks for $\mathrm{BV}$.

\section{Methods}

This study was part of a Cohort Study, including pregnant women, infants and children under five-year-old in Kecamatan Jatinangor, Kabupaten Sumedang, Jawa Barat, conducted in the collaboration of multiple sectors. This cross-sectional descriptive study was carried out in March 2014. The samples of vaginal
Table 1 Prevalence of Microorganism among Pregnant Women in Jatinangor

\begin{tabular}{lc}
\hline \multicolumn{1}{c}{ Infection } & $\begin{array}{l}\text { Cases } \\
\mathbf{n ~ ( \% )}\end{array}$ \\
\hline Bacterial vaginosis only & $10(17.85 \%)$ \\
Mixed infection & $8(14.29 \%)$ \\
Negative BV & $38(67.86 \%)$ \\
Total & $56(100 \%)$ \\
\hline
\end{tabular}

Note: BV: bacterial vaginosis, Mixed infection: infection of both Bacterial vaginosis and vulvovaginal candidiasis

secretion collected from healthy pregnant women living in Desa Cipacing, Kecamatan Jatinangor, Kabupaten Sumedang, Jawa Barat. This study was conducted with approval by the Health Research Ethics Committee, Faculty of Medicine, Universitas Padjadjaran.

The estimated minimal sample size was 53 , however, a total of 56 pregnant women aged older than 15 years old were included. After obtaining verbal and written informed consent, the interview session was initiated using questionnaire forms consisted of details of personal hygiene practices. Following speculum examination, the vaginal discharge was collected using a cotton-tipped swab, suspended in 1.5 milliliters of $\mathrm{NaCl}$ in a plastic transport tube. Specimen collection was performed by a qualified midwife in charge.

Each of the samples collected was stored temporarily in a transport container with ice

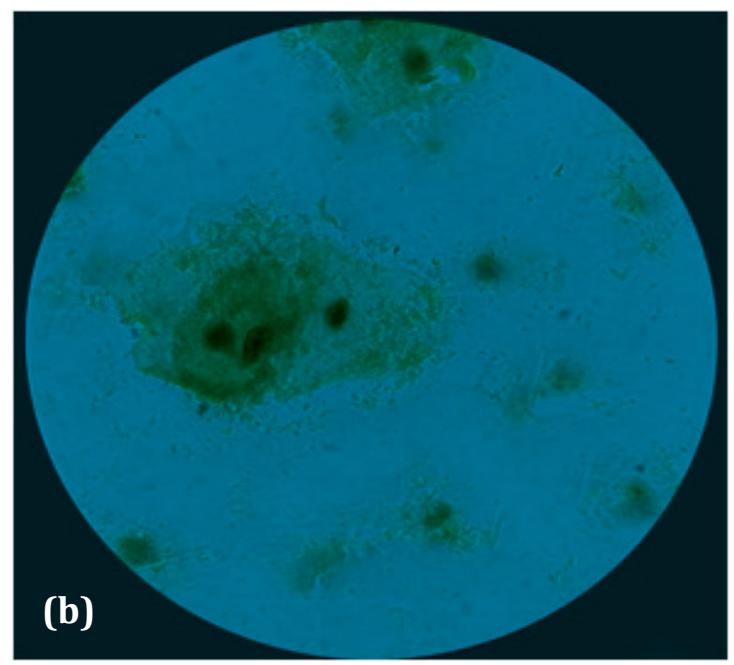

Figure 1 (a)Gram-stained Vaginal Smear of Normal Vaginal Flora (b)Gram-stained Vaginal Smear from the Woman with Positive Bacterial Vaginosis 
Table 2 Characteristics of Pregnant Women Infected with Bacterial Vaginosis $(n=18)$

\begin{tabular}{lc}
\hline \multicolumn{1}{c}{ Characteristics } & $\begin{array}{c}\text { Frequency } \\
\text { n }\end{array}$ \\
\hline Age (Years) & 11 \\
$<25$ & 5 \\
$25-34$ & 2 \\
$>34$ & 2 \\
Educational Level & 4 \\
Elementary School & 11 \\
Junior High School & 1 \\
Senior High School & \\
University Graduate & \\
Parity & 9 \\
Nulliparity & 6 \\
Primiparity & 3 \\
Multiparity & 3 \\
Gestational Age (weeks) & 9 \\
$0-14$ & 6 \\
15-28 & \\
29-42 & \\
\hline
\end{tabular}

packs before being sent to the microbiology laboratory for the detection of pathogens at the Faculty of Medicine, Universitas Padjadjaran.

Gram-stained smears were observed microscopically and accessed using the Nugent score for BV. The result was reported as positive BV when the smear had a Nugent Score of 7 to 10, after quantifying 3 bacterial morphotypes (Lactobacilli, Gardnerella vaginalis and Mobiluncus species); while negative BV was reported when the smear showed a Nugent Score of 0 to 3. Under direct microscopic observation, other microorganisms such as trichomoniasis and candidiasis could be detected.

\section{Results}

In total, 56 pregnant women aged between 17 and 44 (mean age 28 years old) were included, and $17.9 \%(\mathrm{n}=10)$ was infected with BV only; whereas $14.29 \%(n=8)$ had mixed infection with both BV and vulvovaginal candidiasis (VVC) as shown in Table 1. The microorganism under the microscope had been shown in Figure 1.
The characteristic among pregnant women with positive BV was presented (Table 2). The age range of women with positive BV was 15 to 37 years old; $61.1 \%$ completed upper secondary school. Half of the pregnant women with positive BV were nullipara and commonly occurred in second-trimester pregnancy or gestational age of 15-28 weeks. Furthermore, personal hygiene practices of pregnant women with BV infection were presented in Table 3.

\section{Discussion}

The prevalence of Bacterial Vaginosis in this study is comparable to the WHO report. ${ }^{6}$ Another study in India has a similar result among young women in reproductive age. ${ }^{12}$ However, a higher BV prevalence $(30.7 \%)$ has been reported among Indonesian pregnant women elsewhere. ${ }^{9}$ Even more, in Nepalese pregnant women, BV infection was detected

\section{Table 3 Personal Hygiene Practices of Pregnant Women Infected with Bacterial Vaginosis}

\begin{tabular}{|c|c|}
\hline $\begin{array}{c}\text { Personal Hygiene } \\
\text { Practice }\end{array}$ & $\begin{array}{c}\text { Frequency } \\
\mathbf{n}\end{array}$ \\
\hline $\begin{array}{l}\text { Usual underwear } \\
\text { material }\end{array}$ & 11 \\
\hline Cotton & 6 \\
\hline Hosiery & 1 \\
\hline \multicolumn{2}{|l|}{ Others } \\
\hline $\begin{array}{l}\text { Agent used for genital } \\
\text { area cleaning }\end{array}$ & 10 \\
\hline Water & 1 \\
\hline Body wash & 7 \\
\hline \multicolumn{2}{|l|}{$\begin{array}{l}\text { Feminine hygiene } \\
\text { products }\end{array}$} \\
\hline $\begin{array}{l}\text { Ways of genital area } \\
\text { cleaning }\end{array}$ & 14 \\
\hline Front to back & 2 \\
\hline Back to front & 2 \\
\hline \multicolumn{2}{|l|}{ Random } \\
\hline \multicolumn{2}{|l|}{$\begin{array}{l}\text { Hand washing before } \\
\text { and after genital area } \\
\text { cleaning }\end{array}$} \\
\hline Always & 11 \\
\hline Never & 1 \\
\hline Sometimes & 6 \\
\hline
\end{tabular}


in $52.6 \%{ }^{13}$ Hence, the much lower rate of BV prevalence in our study may be due to the difference in methodology; which is Nugent's criteria vs. Amsel' s criteria in Nepal. ${ }^{10,13}$ Nugent scoring system is considered as the gold standard for BV diagnosis, but unfortunately, due to its time-consuming methodology and the costly needs of lab equipment and experts for its interpretation, most of the clinicians are unable to utilize the method effectively. ${ }^{10}$

Based on the result of our study, the highest frequency of BV infection is among women aged $<25$ years. This corresponds to a recent study in Nigeria ${ }^{10}$ and India. ${ }^{13}$ However, an older age group with BV infection was also reported to be around 26 to 40 years old, ${ }^{9}$ suggesting that the BV infection is a common finding within the childbearing age. Thus, the sexually active age group has a risk factor of BV infection and promiscuity even more. ${ }^{2,5}$ Interestingly, the estimated prevalence of symptomatic and asymptomatic BV infection is around $30 \%$ in the general population of women aged 14 to 49 years, ${ }^{14}$ indicating that sexual activity and the number of lifetime sexual partners could be factors contributing to BV prevalence.

Pregnant women with nulliparity are more prone to BV infection compared to primipara and multipara, however, a previous study has shown that BV prevalence was high in women with a history of parity $\leq 2 .{ }^{15}$ In contrast, another study has reported women with parity $>5$ with the highest $\mathrm{BV}$ prevalence. ${ }^{9}$ The parity might not have a significant correlation to $\mathrm{BV}^{9}{ }^{9}$ The present study has shown that BV among pregnant women mostly occurs in second-trimester pregnancy or gestational age of 15-28 weeks, following with the study in Nigeria. ${ }^{10}$

Since BV was prevalent among these pregnant women, the exploration for a better look upon the link between personal hygiene practices and BV is warranted. Hence, this illustrates the necessity of targeted interventions at associated hygienic behavior to reduce BV prevalence. Previous studies hold some questions about the potential risks of wearing nylon and synthetic types underwear to the development of reproductive tract infections since the poor perspiration absorption and maintenance of perineal humidity disadvantages may enable the disturbance of normal vaginal flora. ${ }^{11,16}$ However, the present study has found no difference to this aspect though cotton underwear is strongly encouraged by gynecologists due to its excellent ventilation with a contribution to the maintenance of the vulvar microbiota. ${ }^{17}$ Pregnant women with BV infection were highly used to wear cotton panties daily. Following the cotton material as the most preferred type of underwear among subjects in this study, hosiery type underwear also showed high popularity among pregnant women with BV infection, as shown in another study that there is an increased frequency of genital infection with the use of cotton and hosiery type of underwear. ${ }^{11}$

In pregnant women with $\mathrm{BV}$ infection, water has been used to clean the genital area followed by the use of feminine hygiene products. This result is on contrary to the previous report showing a lower frequency of genital infections among those who have used water for cleaning the genital area. ${ }^{11}$ Interestingly, some feminine hygiene products currently available in the market do not provide protection against vaginitis and even have harmful effects on the vaginal immune barrier and thus may increase the susceptibility to infections. ${ }^{18}$

Most of the pregnant women have practiced front to back cleaning in the perineal area, only a few have a wrong genital area hygiene cleaning practices, i.e. back to front or random which may cause the transfer of microorganisms from the anus to the vagina, ${ }^{11}$ indicating that most of the women in the community have performed perineal cleaning correctly. The normal intestinal flora Escherichia coli ( $E$ coli) is the predominant uropathogenic organism in women suffering from urinary tract infections (UTIs), thus cleaning genitals from front to back is associated with a reduced frequency of UTI instead of BV infection. ${ }^{19,20}$ As for hand washing, most of the pregnant women stated to have their hands washed each time before and after cleaning their genital area. This is in contrast with the previous study showing that genital infections are the least found among those with the habit of often washing hands before and after using the toilet. ${ }^{11}$

This study still held some limitations. Information bias may occur during the interview session because requesting personal hygiene practices is a sensitive issue. Further research concerning the factors which influence the host susceptibility to BV should be performed to provide beneficial information and recommendations in the reproductive health care of pregnant women. These factors including multiple sexual partners, coital frequency, toilet behavior, use of douche, uncircumcised partner, previous medical history of genital tract infection and so on. Healthcare providers who are in charge of reproductive-aged patients 
should be concerned about this issue and give appropriate advice regarding feminine hygiene care. More comprehensive and precise studies are needed to reveal any relationships between personal hygiene practices and associated genital infections.

To conclude, the bacterial vaginosis prevalence among pregnant women in Desa Cipacing, Kecamatan Jatinangor is $17.9 \%$. Proper education and training programs by a healthcare professional on genital hygiene practices which area a crucial aspect of women's health are useful.

\section{Acknowledgments}

We express our sincere gratitude especially to Dr. RTD Judistiani, the principal investigator for the Cohort Study of Pregnant Women, Infants and Children under Five Years Old in Kecamatan Jatinangor who has allowed us to participate in conducting the present study as part of the cohort study. We are thankful to all the staff and students of the Midwifery Diploma Program, a staff of Department Epidemiology and Biostatistics, a staff of Department Microbiology who contributed to this study and all the pregnant women for their participation and cooperation during the study.

\section{References}

1. Singh A, Walia I, Dhaliwal L, editors. Demedicalizing women's health. New Delhi: Gyan Publishing House; 2010

2. Centers for Disease Control and Prevention. Bacterial vaginosis:CDC fact sheet. 2010[cited 2014 February 8]; Available from: http://www.cdc.gov/std/ bv/stdfact-bacterial-vaginosis.htm.

3. Cunningham FG, Leveno KJ, Bloom SL, Hauth JC, Rouse D, Spong CY. Williams obstetrics. $23^{\text {rd }}$ ed. New York City: McGrawHill; 2010. p. 813-4.

4. Donati L, Di Vico A, Nucci M, Quagliozzi L, Spagnuolo T, Labianca A, et al. Vaginal microbial flora and outcome of pregnancy. Arch Gynecol Obstet. 2010;281(4):589600.

5. Kenyon C, Colebunders R, Crucitti T. The global epidemiology of bacterial vaginosis: a systematic review. Am J Obstet Gynecol. 2013;209(6):505-23.

6. Thinkhamrop J. Antibiotics for treating bacteria vaginosis in pregnancy: RHL commentary (last revised: 4 July 2007).
The WHO Reproductive Health Library. Geneva: World Health Organization [cited 2014 February 8]; Available from: https:// extranet.who.int/rhl/es/node/75891.

7. Soper DE. Genitourinary infections and sexually transmitted diseases. In: Berek JS, editor. Berek \& Novak's Gynecology. $14^{\text {th }}$ ed. Philadephia: Lippincott Williams \& Wilkins; 2007. p. 542-7.

8. Pusat Kesehatan Masyarakat (Puskesmas) Jatinangor. Hasil Cakupan Kesehatan Kecamatan Jatinangor 2013. Sumedang: Pusat Kesehatan Masyarakat (Puskesmas) Jatinangor; 2013

9. Ocviyanti D, Rosana Y, Olivia S, Darmawan F. Risk factors for bacterial vaginosis among Indonesian women. Med J Indones. 2010;19(2):130-5.

10. Ibrahim SM, Bukar M, Galadima G, Audu BM, Ibrahim HA. Prevalence of bacterial vaginosis in pregnant women in Maiduguri, North- Eastern Nigeria. Niger J Clin Pract. 2014;17(2):154-8.

11. Sevil S, Kevser O, Aleattin U, Dilek A, Tijen N. An evaluation of the relationship between genital hygiene practices and genital infection. Gynecol Obstet. 2013;3(6):1-5.

12. Madhivanan $P$, Krupp K, Chandrasekaran V, Karat C, Arun A, Cohen C, et al. Prevalence and correlates of bacterial vaginosis among young women of reproductive age in Mysore, India. Indian J Med Microbiol. 2008;26(2):132-7.

13. Shrestha S, Tuladhar N, Basnyat S, Acharya G, Shrestha P, Kumar P. Prevalence of vaginitis among pregnant women attending Paropakar Maternity and Women's Hospital, Thapathali, Kathmandu, Nepal. Nepal Med Coll J. 2011;13(4):293-6.

14. Koumans EH, Sternberg M, Bruce C, McQuillan G, Kendrick J, Sutton M, et al. The prevalence of bacterial vaginosis in the United States 2001-2004 associations with symptoms, sexual behaviors, and reproductive health. Sex Transm Dis. 2007;34(11):864-9.

15. Ajani G, Oduyebo O, Haruna M, Elikwu C. Nugent scores of pregnant women in a tertiary institution in Nigeria. Adv Microb. 2012;2(4):531-6.

16. Klebanoff MA, Nansel TR, Brotman RM, Zhang J, Yu KF, Schwebke JR, et al. Personal hygienic behaviors and bacterial vaginosis. Sex Transm Dis. 2010;37(2):94-9.

17. Runeman B, Rybo G, Forsgren-Brusk U, Larko O, Larsson P, Faergemann J. The vulvar skin microenvironment: impact of tight-fitting underwear on microclimate, 
pH and microflora. Acta Derm Venereol. 2005;85(2):118-22.

18. Fashemi B, Delaney ML, Onderdonk AB, Fichorova RN. Effects of feminine hygiene products on the vaginal mucosal biome. Microb Ecol Health Dis. 2013;24:1-6.

19. Brooks G, Carroll KC, ButelJ, MorseS. Enteric Gram-Negative Rods (Enterobacteriaceae). In: Brooks G, Butel J, Carroll KC, Morse $\mathrm{S}$, Mietzner T, editors. Jawetz Melnick
\& Adelbergs Medical Microbiology $25^{\text {th }}$ ed. New York City: McGraw-Hill Medical; 2010. p. 217-8.

20. Moustafa MF, Makhlouf EM. Association between the hygiene practices for genital organs and sexual activity on urinary tract infection in pregnant women at women's health center, at Assiut University Hospital. J Am Sci. 2012;8(9):512-22. 